\title{
GAYA BAHASA DAN PESAN MORAL DALAM PUISI TERPILIH WILLIAM SHAKESPEARE
}

\author{
Galuh Anggraini ${ }^{1}$ \\ Soenarjati Djajanegara² \\ Program Studi Pendidikan Bahasa Inggris Universitas Indraprasta PGRI \\ email: anggrainiraini60@gmail.com ${ }^{1}$ \\ email: djajanegara.soenarjati.unindra.ac.id ${ }^{2}$
}

\begin{abstract}
The aim of the research is to find out the use of figurative languages, the dominant one, and the moral values in the selected poems of William Shakespeare. This research uses a qualitative descriptive method. There are 14 kinds of figurative language used in the selected poems, they are metaphor, simile, symbol, personification, litotes, hyperbole, metonymy, synecdoche, allusion, alliteration, repetition, assonance, parallelism, and paradox. The dominant of figurative language used in the selected poems is metaphor. There are five moral values, such as appreciate, joy, love, honesty, and loyalty.

Keywords: literature; figurative language; moral value; poetry
\end{abstract}

\section{Pendahuluan}

Bahasa adalah alat komunikasi antara anggota masyarakat berupa simbol bunyi yang dihasilkan oleh alat ucap manusia. Keraf (2004, p. 1) Bahasa juga sebagai sarana seseorang dalam menuangkan gagasan dan perasaan mereka, bahkan bahasa juga merupakan sebuah sarana seseorang dalam menciptakan sebuah karya sastra baik itu berupa lisan maupun tulisan. Perkembangan bahasa saat ini sangat pesat, namun hal ini rupanya tidak seimbang dengan perkembangan karya sastra. Karya sastra pada masa kini tidak mengalami perkembangan yang cukup pesat, justru terkesan mengalami penurunan atau kemerosotan dari masa sebelumnya. Banyak di antara karya sastra yang seakan kehilangan kharismanya di dalam kehidupan sehari-hari. Meski pada kenyataannya ditemui banyak jenis karya sastra seperti novel dan lagu-lagu yang sering dibaca dan didengarkan. Menurut Wicaksono (2014, p. 1) "sastra merupakan seni kreatif yang objeknya adalah manusia dan kehidupan dengan menggunakan bahasa sebagai mediumnya." Terdapat banyak genre dari sebuah karya sastra yang berupa puisi, lirik, sajak, drama, novel dan cerita. Gaya bahasa merupakan salah satu unsur intrinsik penting dalam puisi yang karenanya juga berfungsi untuk memperindah puisi tersebut melalui penggunaan bahasanya (Nurgiyantoro, 2015). Pemilihan gaya bahasa dalam puisi klasik yang ditulis Shakespear, pembaca akan terbawa dengan pilihan kata yang dipilihnya. Gaya bahasa simile, metafora, hiperbola, personifikasi, dan repitisi dalam puisi Shakespear, namun metafora merupakan ciri khas puisi yang ditulisnya (Raflis \& Zai, 2018).

Selain gaya bahasa, pembaca pasti menemukan sesuatu dalam perenungannya saat dan setelah membaca puisi. Kesan tersebut dapat berupa pesan moral. Pesan moral adalah standar baik dan buruk yang terbentuk berdasarkan pilihan dan tingkah laku seseorang. Dalam sebuah karya sastra yang merupakan hasil dari pemikiran atau gagasan seseorang yang dituangkan melalui bahasa tentunya mengandung nilai-nilai moral maupun pesan moral di dalamnya. Lebih lanjut lagi, nilai moral atau pesan moral yang terkandung dalam setiap karya sastra memiliki hubungan dengan tema dari karya sastra tersebut. Nilai moral ataupun pesan moral dapat disampaikan oleh penyair baik secara jelas maupun tersirat, sehingga sebagai pembaca karya-karya sastra perlu pemahaman lebih dalam untuk mendapatkan pesan yang ingin disampaikan oleh penyair kepada pembaca karena memahami gagasan seseorang hanya melalui rangkaian kata-kata, terlebih lagi rangkaian kata-kata yang sepenuhnya berbentuk majas bukanlah hal yang mudah. 
INFERENCE: Journal of English Language Teaching

Vol. 3, No. 2, August - November 2020

p-ISSN: 2615-8671

e-ISSN: 2615-868X

Wellek dan Waren (1989, p. 3) menyatakan "sastra adalah suatu kegiatan kreatif, sebuah karya seni." Sementara, Winarni (dalam Wicaksono, 2014, p. 3) mengemukakan bahwa "sastra adalah hasil kreativitas pengarang yang bersumber dari kehidupan manusia secara langsung melalui rekaan dengan bahasa sebagai medianya

Waluyo (2000, p. 118) menyatakan, puisi adalah "karya sastra dengan gaya bahasa yang dipadatkan, dipersingkat, dan diberi irama dengan bunyi yang padu dan pemilihan kata-kata kias (imajinatif)." Sebagai bagian dari karya sastra, puisi memiliki unsur pembentuk. Waluyo (2000, p. 119) membagi ciri-ciri kebahasaan puisi menjadi struktur fisik atau struktur kebahasaan dan struktur batin puisi. Struktur fisik puisi terdiri dari: tipografi (pengaturan penulisan); larik/baris; bait (kumpulan larik); diksi (pemilihan kata); imaji; kata konkret; bahasa figuratif; versifikasi; dan makna. Unsur batin puisi, di antaranya: tema (sense); rasa (feeling); nada (tone); dan amanat (intention).

Moral berasal dari kata mos (mores) yang sinonim dengan kesusilaan, tabiat, atau kelakuan. Menurut Vaughn (2014, p. 13): “morality refers to beliefs concerning right and wrong, good and badbeliefs that can conclude judgments, values, rules, principles, and theories. These beliefs help our action, define our values, and give us reasons for being the persons we are." Nugiyantoro (2010, p. 321) mengemukakan bahwa moral dalam karya sastra dapat dipandang sebagai amanat, pesan, message. Moral dalam karya sastra biasanya mencerminkan pandangan hidup pengarang yang bersangkutan, pandangannya tentang nilai-nilai kebenaran, dan hal itulah yang ingin disampaikannya kepada pembaca (Nurgiyantoro, 2010). Moral adalah sebuah pesan kebaikan dalam karya sastra yang disampaikan kepada para pembaca karya sastra. Sehubungan dengan latar belakang yang telah dikemukakan di atas, analisis ini menguji adanya gaya bahasa, gaya bahasa dominan, dan pesan moral (amanat) yang terdapat di dalam puisi-puisi William Shakespeare.

\section{Metode Penelitian}

Penelitian ini menggunakan pendekatan kualitatif deskriptif. Menurut Bongdan dan Tylor (dalam Moleong, 2017, p. 4), penelitian kualitatif adalah sebuah prosedur penelitian yang menghasilkan data deskriptif berupa kata-kata tertulis maupun lisan dari orang-orang dan perilaku yang diamati. Penelitian berfokus dalam mendeskripsikan hasil temuan, sehingga pendekatan yang tepat untuk digunakan adalah penelitian kualitatif deskriptif. Penelitian ini dirancang untuk mendeskripsikan jenis dan nilai moral dari gaya bahasa pada puisi terpilih karangan William Shakespeare. Fokus penelitian adalah unsur intrinsik puisi dengan subfokus gaya bahasa dan pesan/nilai moral.

Instrumen dalam penelitian ini adalah peneliti sendiri, karena penelitian ini merupakan penelitian kualitatif. Penelitian kualitatif sebagai human instrument berfungsi menetapkan fokus penelitian, memilih informasi sebagai sumber data, menilai kualitas data, analisis data, menafsirkan data dan membuat simpulan atas temuannya. Puisi yang dianalisis adalah puisi karangan William Shakespeare yang merupakan puisi berjenis soneta dengan jumlah sekitar delapan puisi yang dirasa cukup untuk mewakili 154 soneta yang ditulis oleh Shakespeare (Shakespeare Online, 2019a).

Setelah data terkumpul maka akan dilakukan uji keabsahan data, untuk membuktikan bahwa penelitian dapat dipertanggungjawabkan dan valid. Adapun uji keabsahan data yang dapat dilaksanakan dalam penelitian kualitatif (Sugiyono, 2016), di antaranya: (1) Credibility; (2) Transferability; (3) Dependability; (4) Confirmability. Pengecekan keabsahan data peneliti ini sendiri menggunakan teknik triangulasi. Menurut Moleong (2017, p. 330) triangulasi merupakan teknik pemeriksaan keabsahan data yang memanfaatkan sesuatu yang lain. 


\section{Hasil dan Pembahasan}

Setelah dilaksanakannya penelitian ini, maka ditemukan adanya gaya bahasa dalam puisi-puisi William Shakespeare, yaitu: 13 metafora (17,57\%), 4 similes $(5,41 \%), 5$ simbol $(6,76 \%), 9$ personifikasi $(12,16 \%), 1$ litotes $(1,35 \%), 4$ hiperbola $(5,41 \%), 4$ metonimia $(5,41 \%), 1$ sinekdoke $(1,35 \%), 2$ alusio $(2,70 \%), 10$ aliterasi $(13,51 \%), 10$ repetisi, 6 asonasi $(8,11 \%), 3$ paralelisme $(4,05 \%)$, dan 2 paradoks $(2,70 \%)$. Total temuan adalah 74 gaya bahasa.

Tabel 1. Rangkuman Nilai Moral dalam Puisi

\begin{tabular}{|c|c|c|c|c|c|c|c|}
\hline \multirow{2}{*}{ No. } & \multirow{2}{*}{ Soneta } & \multicolumn{6}{|c|}{ Moral Value } \\
\hline & & Appreciate & Honesty & Joy & Karma & Love & Loyalty \\
\hline 1. & XVIII & $\mathrm{V}$ & & & & & \\
\hline 2. & XXIX & & & V & & & \\
\hline 3. & LV & & & & & $\mathrm{V}$ & \\
\hline 4. & CXIII & & & & & $\mathrm{V}$ & \\
\hline 5. & CXIV & & & & & $\mathrm{V}$ & \\
\hline 6. & CXVI & & & & & V & \\
\hline 7. & CXXXVIII & & $\mathrm{V}$ & & & & \\
\hline 8. & A Fairy Song & & & & & & $\mathrm{V}$ \\
\hline
\end{tabular}

\section{Sonnet XVIII}

Q1

Shall I compare thee to a summer's day?

Thou art more lovely and more temperate

Rough winds do shake the darling buds of may

And summer's lease hath all to short a date.

$$
\text { Q2 }
$$

Sometime too hot the eye of heaven shines

And often is his gold complexion dimmed

And every fair from fair sometime declines

By chance, or nature's changing cours untrimmed

$$
\text { Q3 }
$$

But thy eternal summer shall not fade

Nor lose possession of that fair thou ow'st

Nor shall death brag thou wonders'st in his shade

When in eternal lines to time thow grow'st.

$$
\text { C }
$$

So long as men can breathe or eyes can see

So long live this, and this gives life to thee

Puisi ini merupakan puisi yang mengungkapkan kekaguman penyair atas kecantikan kekasihnya (Shakespeare Online, 2019e). Di dalam sonata XVIII ini terdapat tujuh gaya bahasa, yaitu: metafora, personifikasi, symbol, repetisi, aliterasi, asonasi, dan paralelisme. "Shall I compare thee to a summer's day?" dan "But thy eternal summer shall not fade" merupakan metafora karena membandingkan kecantikan wanita dan tidak cepat hilang seperti keindahan musim panas. Terdapat 
INFERENCE: Journal of English Language Teaching

Vol. 3, No. 2, August - November 2020

p-ISSN: 2615-8671

e-ISSN: 2615-868X

repetisi (pengulangan kata) pada quatrain 1 (Q1) "more"; quatrain 2 (Q2) "fair"; dan pada couplet "this". Lebih lanjut, personifikasi pada "Rough winds do shake the darling buds of May" dan "Sometime too hot the eye of heaven shines", kata "shake" dan "the eye" merupakan atribut dari makhluk hidup. Kata "the eye" merupakan simbol dari matahari. Pada quatrain 2 (Q2), "fair from fair"merupakan aliterasi " $\mathrm{f}$ ". Terdapat asonasi "o" dan paralelisme " so long" pada couplet.

Di dalam sonata XVIII ini, terdapat pesan moral berupa menghargai dan pujian tentang keindahan dari cinta (kekasihnya). Hal ini ditunjukkan pada semua bagian puisi yang menyatakan keindahan cinta berbeda dengan musim panas dan tidak akan pernah luntur seiring waktu atupun menghilang karena berbagai hal.

\section{Sonnet XXIX}

Q1

When, in disgrace with fortune and men's eyes,

I all alone beweep my outcast state

And trouble deaf heaven with my bootless cries, And look upon myself and curse my fate,

Q2

Wishing me like to one more rich in hope,

Featured like him, like him with friends possess'd,

Desiring this man's art and man's scope,

With what I most enjoy contented least;

Q3

Yet in this thoughts myself almost despising,

Haply I think on thee, and then my state,

Like to the lark at break of day arising

From sullen earth, sings hymns at heaven's gate;

C

From thy sweet love remember'd such wealth brings

That then I scorn to change my state with kings.

Puisi ini menggambarkan keadaan hidup penyair pada masanya (Shakespeare Online, 2019f). Sonata XXIX ini terdapat sembilan gaya bahasa, yaitu: metafora, simile, personifikasi, symbol, hiperbola, litotes, paradoks, repetisi, dan aliterasi. "Wishing me like to one more rich in hope, featured like him, like him with friends possess' $d$, desiring this man's art and man's scope" merupakan metafora, karena bermakna bahwa penyair menginginkan apa yang dimiliki oleh laki-laki lain. Selain itu terdapat simile karena membandingkan keadaannya dan objek lainnya dengan menggunakan kata "like" pada "like to one more rich", "featured like him", dan "like to the lark". Lebih lanjut, "trouble deaf heaven" dan "sullen earth" merupakan personifikasi karena "deaf" dan "sullen" merupakan atribut makhluk hidup. "And trouble deaf heaven with my bootless cries" merupakan hiperbola karena pernyataannya dilebih-lebihkan. "My state" merupakan simbolisasi dari perasaan sedih penyair. Pada Q2 merupakan litotes karena merendahkan dirinya dan menyatakan tidak beruntung. Hal ini berbeda dengan pengungkapan keseluruhan bait yang menyatakan meski menderita namun dia juga merasakan keberuntungan. "I most enjoy contented least" merupakan paradoks, karena penyair merasakan nyaman tapi kenyataannya penyair tidak cukup bahagia akan keadaannya. Selain itu, terdapat gaya bahasa repetisi karena penggulangan kata "like", "him", dan "man 's". Terdapat juga gaya bahasa aliterasi, yaitu aliterasi "th" pada "think on thee, and then".

Dalam sonata XXIX ini, pesan moral yang terkandung adalah sesulit apapun hidup akan tetap terasa berharga karena kita memiliki orang yang kita cintai, sekalipun itu hanya berupa kenangan. Hal ini ditunjukkan pada Q1 menyatakan tentang nasib buruk dan ketidak- beruntungan seorang pria dalam kehidupannya. Seakan-akan surga pun tak memperdulikannya. Pada Q2 menunjukkan bahwa penyair merasa tidak puas dengan kehidupannya sendiri dan merasa iri dengan kehidupan orang lain. Pada Q3 menunjukkan perubahan suasana hati atau sikap jika dibandingkan dengan quatrain pertama dan kedua 
yang menyatakan kesedihan dan rasa keputusasaan. Pada couplet (C) mengungkapkan betapa penyair setidaknya merasa beruntung memiliki orang yang dicintai yang tidak dapat ditukar dengan apapun.

\section{Sonnet LV}

Q1

Not marbel, nor the gilded monuments

Of princes, shall outlive this powerful rhyme;

But you shall shine more bright in these contents

Than unswept stone basmear'd with sluttish time.

Q2

When wasteful war shall statues overtrun,

And broils root out the work of mosanry,

No Mars his sword nor war's quick fire shall burn

The living record of your memory.

Q3

'Gainst death and oblivious enmity

Shall you pace forth; your praise shall still find room

Even in the eyes of all posterity

That wear this world out to the ending doom.

C

So, till the judgment that yourself arise,

You live in this, and dwell in lovers' eyes.

Puisi ini menceritakan kisah cinta penyair ke pada gadis yang dicintai (Shakespeare Online, 2019g). Sonata LV ini terdapat tiga gaya bahasa, yaitu: metafora, aliterasi, dan repetisi. Gaya bahasa metafora terdapat pada kalimat "Not marbel, nor the gilded monuments", penyair berusaha membandingkan usia puisinya dengan karya seni lainnya. Lebih lanjut terdapat gaya bahasa repetisi, karena terdapat pengulangan kata "shall" dan "in" Q3 dan C (couplet). Gaya bahasa aliterasi terdapat pada quatrain ke 2, quatrain ke 3, dan couplet, yaitu aliterasi "w" pada "When wasteful war"; aliterasi "s", "y", "p", "f", "t", dan "w" pada "Shall you pace forth; your praise shall still find room" dan "That wear this world out to the ending doom"; aliterasi " $\mathrm{t}$ " pada "till the judgment that".

Pesan moral yang terkandung adalah keabadian cinta. Pada Q1, dijelaskan cinta penyair kepada kekasihnya tidak akan pernah termakan oleh waktu, tidak seperti prasasti atau monumen yang akan hancur seiring berjalannya waktu meskipun terbuat dari batu yang kokoh. Pada Q2 menjelaskan bahwa perang ataupun hal-hal yang bersifat merusak tidak akan mampu menghancurkan ingatan-ingatan tentang kisah cinta yang akan terus ada. Kata "The living record of your memory", kata ini yang memperkuat pernyataan kisah dalam puisi tidak akan dapat dihancurkan karena akan tetap tersimpan di dalam ingatan. Pada Q3, menjelaskan bahwa kisah cinta abadi akan selamanya akan tetap terkenang atau ada di masa yang akan datang hingga akhir zaman (to the ending doom). Pada couplet, mempertegas penyataan yang dinyatakan di dalam tiga couplet di atas, bahwa kisah cintanya akan tetap abadi dan akan terdengar jelas kembali di hari penghakiman, meski saat ini hanya dapat diungkapkan melalui kata-kata di dalam sebuah puisi.

\section{Sonnet CXIII}

Q1

Since I left you, mine eye is in my mind And that which governs me to go about

Doth part his function, and is partly blind

Seems seeing, but effectually is out:

$$
\text { Q2 }
$$

For it no form delivers to the heart

Of bird, of flower, or shape which it doth latch

Of his quick objects hath the mirce no part 
INFERENCE: Journal of English Language Teaching

Vol. 3, No. 2, August - November 2020

p-ISSN: 2615-8671

e-ISSN: 2615-868X

\author{
Nor his own vision holds what it doth catch \\ Q3 \\ For if it see the rud'st or gentlest sight \\ The most sweet favour or deformed'st creature \\ The mountain, or the sea, the clay, or might: \\ The crow, or dove, it shapes them to your feature \\ $C$ \\ Incapable of more, replete with you \\ My most true mind thus maketh mine untrue
}

Dalam puisi ini diceritakan mengenai penyair yang hati dan pikirannnya dipenuhi oleh bayangan kekasihnya, karena baginya kekasihnya adalah inspirasi satu-satunya (Shakespeare Online, 2019b). Di dalam sonata CXIII ini terdapat enam gaya bahasa, yaitu: metafora, hiperbola, metonimia, paralelisme, aliterasi, dan asonasi. "mine eye is in my mind" adalah metafora karena membandingakan fungsi pengelihatan dengan pemikiran. Menyatakan pikirannya tidak berjalan sebagaimana mestinya dan mengganggu pengelihatannya. Lebih lanjut, "for if it see the rud'st or gentlest sight; the most sweet favour or deformed'st creature; the mountain, or the sea, the clay, or might:; the crow, or dove, it shapes them to your feature; incapable of more, replete with you" merupakan hiperbola karena penyair menyatakan apapun yang dilihatnya berubah menjadi bayangan sang kekasih, selain itu juga terdapat gaya bahasa paralelisma karena memiliki pola tatanan bahasa yang sama. Selanjutnya terdapat gaya bahasa metonimia, "doth part his function, and is partly blind, seems seeing, but effectually is out:"; "for it no form delivers to the heart"; dan "incapable of more, replete with you, my most true mind thus maketh mine untrue". Kalimat tersebut menggambarkan ketidakmampuan penyair mengendalikan pikirannya. Terdapat asonasi "o" pada sebagian besar kalimat di setiap bait (quatrain). Terdapat aliterasi "m" pada kalimat "mine eye is in my mind" dan "my most true mind thus maketh mine untrue".

Di dalam sonata CXIII ini, terdapat pesan moral tentang ketergantungan dan cinta yang membutakan mata hati. Hal ini ditunjukkan pada Q1, menyatakan bahwa sejak terpisah dengan kekasihnya, penyair seakan kehilangan seluruh kemampuannya. Pada Q2, dinyatakan berbagai macam bentuk yang ada di alam semesta tidak dapat menyentuh hatinya. Pada Q3, penyair mengamati segala macam yang ada di dunia, namun tetap saja berubah menjadi bayangan pujaan hatinya. Pada couplet, dinyatakan bahwa penyair sangat tergantung dengan pujaan hatinya. Kata "Incapable", menyatakan ketidak-mampuan penyair dalam melakukan banyak hal (membuat syair maupun puisi) karena seluruh pikiran dan hatinya dipenuhi oleh pujaan hatinya. Bagi penyair, kekasihnya adalah segalanya, merasakan sosok pujaan hati dalam segala hal. Baginya sang pujaan hati adalah inspirasi satu-satunya.

\title{
Sonnet CXIV \\ $Q 1$
}

They that have power to hurt and will do none,

That do not do the thing they most do show,

Who, moving others, are themselves as stone,

Unmoved, cold, and to temptation slow;

\section{Q2}

The rightly do inherit heaven's graces

And husband nature's riches from expense;

They are the lords and owners of their faces,

Others but stewards of their excellence.

$$
\text { Q3 }
$$

The summer's flower is to the summer sweet,

Though to itself it only live and die,

But if that flower with base infection meet,

The basest weed out-braves his dignity; 


\section{For sweetest things turn sourest by their deeds;}

Lilies that faster smell far worse than weeds.

Puisi ini merupakan puisi yang menceritakan perubahan penilaian sikap yang terjadi pada golongan orang-orang tertentu dikarenakan perbuatan yang mereka lakukan (Shakespeare Online, 2019h). Di dalam sonata CXIV ini terdapat delapan gaya bahasa, yaitu: metafora, simile, hiperbola, metonimia, sinekdoke, asonasi, repetisi, dan aliterasi. Terdapat gaya bahsa metafora, di antaranya: "they that have power to hurt and will do none; unmoved, cold, and to temptation slow", pada Q1 karena membandingkan orang jahat dengan orang baik dan menyamakan suatu golongan berdasarkan sifatnya. "The rightly do inherit heaven's graces; they are the lords and owners of their faces" merupakan metafora karena membandingkan dua elemen kekuatan sosial dan cara mereka mempertahankan sikap dasarnya. "The basest weed out-braves his dignity", merupakan metafora karena menafsirkan "basest weed" sebagai orang kelas bawah yang mencemari orang kelas atas. Selanjutnya, metafora terdapat pada couplet karena membandingkan dua sikap dan kekuatan yang hamper sama.

Terdapat simile karena menyamakan suatu golongan dengan menggunakan kata "as" dalam " themselves as stone". Lebih lanjut, gaya bahasa hiperbola terdapat pada "the rightly do inherit heaven's graces", karena menyampaikan gagasan dengan dilebih-lebihkan dalam menggambarkan seseorang. Terdapat repetisi kata "do", asonasi "o", dan aliterasi "t, d"pada kalimat "that do not do the thing they most do show". Gaya bahasa sinekdoke dan metonimia ditemukan pada kalimat "for sweetest things turn sourest by their deeds; lilies that faster smell far worse than weeds", karena menyatakan sikap orang baik yang tercemar oleh "by their deeds" (perbuatan yang dilakukan), sedangkan "lily" dan "weeds" digunakan untuk menyampaikan gagasan yang mana keduanya adalah jenis dari tumbuhan.

Di dalam sonata ini, nilai moral yang terkandung sangat luas berdasarkan sudut pandang dan pemaknaan para pembaca. Dalam hal ini, nilai moral yang didapatkan adalah seseorang yang berpenampilan baik dengan sikap yang baik atau baik pada penilaian luarnya belum tentu kepribadiaan aslinya juga baik, bisa saja mengandung keburukan. Seperti dalam sonata ini, pada couplet dapat dimaknai juga bahwa adanya penghianatan yang dilakukan oleh orang yang terlihat baik dengan seseorang yang menaruh rasa cinta kepadanya, ia dicampakkan dan melupakan semua yang telah dijanjikannya kepada seseorang yang mencintainya.

Pada Q1, digolongkan beberapa golongan kepribadian yang mana mereka memiliki kekuasaan tetapi tidak digunakan untuk menyakiti orang lain atau melakukan kesenangan. Kata "unmoved, cold" mengekspresikan bahwa mereka yang memiliki kekuasaan tetap bersikap tenang dan dapat mengontrol diri mereka dengan baik. Pada Q2, disebutkan bahwa golongan orang-orang dengan kepribadian seperti pada quatrain pertama mewarisi berkah dari surga. Kalimat "They are the lords and owners of their faces", mengekspresikan bahwa mereka dapat mengontrol diri mereka sendiri dengan baik, sehingga mereka tidak menyakiti orang lain dengan kekuasaan dan kekayaan yang mereka miliki. Pada Q3, menyatakan bahwa perubahan pandangan dan peniliaan dan peniliaan di antara dua golongan atau kelompok kepribadian yaitu: orang baik (golongan atas) dengan orang jahat (golongan kelas bawah). Dalam memberikan gambaran sederhana digunakan perbandingan antara dua jenis tumbuhan "lily" dan "weeds". Pada couplet, dinyatakan bahwa sudut pandang penilaian baik buruknya kepribadian seseorang. Dikatakan bahwa terlepas dari keindahan kepribadian ataupun kelebihan yang dimiliki, nilai dari kepribadian seseorang akan dinilai dari perilaku orang tersebut. Seperti yang diungkapkan pada kalimat "For sweetest things turn sourest by their deeds."

\section{Sonnet CXV1}

$Q 1$

Let me not to the marriage of true minds

Admit impediments. Love is not love

Which alters when it alteration finds,

Or bends with the remover to remove:

$Q 2$

$O$, no! it is an ever-fixed mark,

That looks on tempests and is never shaken; 
INFERENCE: Journal of English Language Teaching

Vol. 3, No. 2, August - November 2020

p-ISSN: 2615-8671

e-ISSN: 2615-868X

It is the star to every wandering bark,

Whose worth's unknown, although his height be taken.

Q3

Love's not Time's fool, though rosy lips and cheeks

Within his bending sickle's compass come;

Love alters not with his brief hours and weeks,

But bears it out even to the edge of doom.

C

If this be error and upon me proved,

I never writ, nor no man ever loved.

Puisi ini merupakan puisi yang menceritakan menggambarkan sifat, sikap, dan bentuk dari cinta yang sebenarnya (Shakespeare Online, 2019c). Di dalam sonata CXVI ini terdapat lima gaya bahasa, yaitu: repetisi, alusio, asonasi, symbol, dan personifikasi. Pada Q1 terdapat repetisi karena adanya pengulangan kata "love", "alter", dan "remove". Pada Q2 terdapat gaya bahasa alusio karena mensugestikan kepada bintang Utara yang digunakan pelaut sebagai petunjuk di lautan dan terdapat asonasi "a" pada kata "mark", "star", dan "bark". Asonasi juga terdapat pada " compass come" yaitu asonasi "o". Lebih lanjut, kata "the edge of doom" merupakan simbol dari hari penghakiman. Gaya bahasa personifikasi terdapat pada kalimat "love's not Time's fool, though rosy lips and cheeks" dan "love alters not with his brief hours and weeks", karena digunakannya atribut "time's fool", "his brief hours and weeks" pada "love".

Di dalam sonata ini, nilai moral yang didapatkan mengenai kebenaran dan kekuatan cinta sejati. Cinta sejati tidak akan pernah berubah ataupun tidak dapat dirusak meskipun banyak rintangan yang dihadapinya. Pada Q1, . Pada quatrain pertama, sonata ini mengungkapkan bahwa cinta sejati tidak akan pernah berubah sedikit pun dan akan tetap sama. Kalimat "Admit impediments" menyatakan bahwa cinta sejati menerima semua kesulitan atau rintangan. Pada Q2, dua kalimat awal yang terkandung merupakan kelanjutan dari couplet pertama yang menyatakan tentang kekokohan cinta sejati. Kalimat "It is the star to every wandering bark" yang menggambarkan cinta sejati seperti bintang di langit yang menunjukkan arah bagi kapal yang tersesat di lautan. Hal ini dapat dimaknai bahwa cinta sejati dapat menuntun hal yang tidak baik kea rah yang lebih baik atau ke jalan yang benar dan tetap kokoh meski terdapat badai besar. Pada Q3, dinyatakan bahwa cinta sejati akan bertahan hingga akhir zaman. Kata "doom" di dalam quatrain ini merupakan symbol untuk kematian. Kata ini sekaligus menegaskan tentang kelebihan cinta sejati lainnya, yaitu tetap akan bertahan meski di ujung kematian ataupun akhir zaman. Pada couplet, penyair memberikan sebuah jaminan tentang kata-katanya yang menggambarkan cinta sejati itu seperti apa. Kalimat "I never writ" di dalam couplet merupakan ungkapan penyair yang menyatakan jika memang tidak ada cinta sejati seperti yang diucapkan, ataupun apa yang dikatakan tentang cinta sejati seperti yang di dalam puisi-puisinya itu, maka penyair akan menarik atau menghapus semua puisi-puisi yang pernah ditulis mengenai cinta.

\section{Sonnet CXXXVIII}

Q1

When my love swears that she is made of truth I do believe her though I know she is lies

That she might think me some untutored youth Unlearned in the world's false subtletis

Q2

Thus vainly thinking that she thinks me young Although she knows my days are past the best Simply I credit her false-speaking tongue

On both side thus is simple truth suppressed Q3

But wherefore says she not she is unjust? And wherefore say not I that I am old? 
O love's best habit is in seeming trust

And age in loves not to have years told

$C$

Therefore I lie with her, and she with me

And in our faults by lies we flattered be

Puisi ini merupakan puisi yang menceritakan kehidupan percintaan yang berdiri di atas kebohongan (Shakespeare Online, 2019d). Di dalam sonata CXXXVIII ini terdapat enam gaya bahasa, yaitu: metafora, personifikasi, paradoks, aliterasi, repetisi, dan paralelisme. Gaya bahasa metafora terdapat pada kalimat "when my love swears that she is made of truth", penyampaian gagasan yang membandingkan kekasihnya dengan kejujuran. "I do believe her though I know she is lies" mengandung paradoks karena berbicara tentang kebenaran bahwa kekasihnya berbohong kepada penyair. Gaya bahasa personifikasi terdapat pada Q2 dan Q3, "her false-speaking tongue", "O love's best habit" dan "age in loves". Pada kalimat tersebut terdapat penggunaan "false speaking" pada lidah dan yang dapat melakukan kesalahan dalam pengucapak bukan lidah tetapi manusia, "best habit" dan " age" pada cinta. Lebih lanjut terdapat aliterasi "s" dan "th" pada kalimat "side thus is simple truth suppressed" dan "Thus vainly thinking that she thinks". Kalinat "but wherefore says she not she is unjust?, and wherefore say not I that I am old?", merupakan repetisi dan paralelisme karena menggunakan tata bahasa yang sama dengan menggunakan pengulangan kata "wherefore says".

Di dalam sonata ini, terdapat pesan moral yang mengajarkan ke pada pembaca untuk tidak berbohong, terlebih lagi mengenai hal-hal penting ke pada pasangan. Pada Q1 menunjukkan bahwa kekasih penyair berbohong mengenai status dirinya yang sebenarnya ke pada penyair. Kata "I do believe her though I know she is lies ", menunjukkan penyair berpura-pura mempercayai apa yang dikatakan oleh kekasihnya, meskipun penyair mengetahui bahwa sang kekasih berbohong. Pada Q2, penyair mengungkapkan bahwa sebenarnya penyair juga berbohong ke pada kekasihnya yang lebih dulu membohonginya. Kebohongan penyair adalah usia. Penyair tidak mengatakan usia yang sebenarnya. Pada Q3, menjelaskan secara sederhana bahwa di antara keduanya saling berbohong dan mengetahui kebohongannya masing-masing. Kalimat "But wherefore says she not she is unjust? And wherefore say not I that I am old?", menggambarkan ke pada pembaca bahwa penyair mengetahui kekasihnya berbohong, dan sang kekasih juga mengetahui sang penyair berbohong ke padanya. Pada couplet, menyatakan kehidupan mereka setelah sama-sama mengetahui mereka saling berbohong satu sama lain. Diungkapkan bahwa sang penyair dan kekasihnya hidup bahagia bersama dengan tetap saling berbohong dan sama-sama menyembunyikan kebenaran akan diri mereka masing-masing.

\section{A Fairy Song}

Q1

Over hill, over dale,

Thorough bush, thorough brier,

Over park, over pale,

Thorough flood, thorough fire!

Q2

I do wander everywhere,

Swifter than the moon's sphere;

And I serve the Fairy Queen,

To dew her orbs upon the green;

Q3

The cowslips tall her pensioners be;

In their gold coats spots you see;

Those be rubies, fairy favours;

In those freckles live their savours;

$\mathrm{C}$

I must go seek some dewdrops here.

And hang a pearl in every cowslip's ear. 
Puisi ini merupakan puisi yang menceritakan kesetiaan (www.WilliamShakespeare.net, 2015). Di dalam sonata "A Fairy Song" ini terdapat enam gaya bahasa, yaitu: simile, simbol, personifikasi, hiperbola, alusio, asonasi, dan repetisi. Gaya bahasa repetisi terdapat pada Q1 karena adanya penggulangan kata "over" dan "thorough". Pada Q2 terdapat gaya bahasa personifikasi dan simile, karena menyatakan dirinya lebih cepat dari perputaran bulan "swifter than the moon's sphere", kalimat tersebut merupakan simile karena menggunakan "than" untuk membandingkan kecepatan dirinya dengan rotasi bulan. "Moon's sphere" merupakan alusio, karena merujuk kepada malam hari. Di dalam puisi ini ditemukan simbol berupa "Fairy Queen" yang bermakna "the maiden" (kekasih) dan "fairy" bermakna "lover". Terdapat juga asonasi "o" dan "f" pada kalimat "gold coats spots you" dan "fairy favours". Lebih lanjut, gaya bahasa personifikasi pada kalimat "and hang a pearl in every cowslip's ear", karena kata "ear" hanya dimiliki manusia dan hewan bukan tumbuhan, sedangkan cowlip merunakan jenis bunga.

Dalam sonata A Fairy Song ini, terdapat pesan moral yaitu kesetiaan. Fairy (pecinta) akan selalu setia dan rela melakukan apapun untuk memberikan apa yang diinginkan oleh Fairy Queen (kekasihnya). Penyair rela melakukan dan memberikan apapun agar kekasihnya merasa bahagia. Pada Q1, penyair menggambarkan kesetiaan dengan menyatakan rela menaiki bukit hingga melewati api. Pada Q2, penyair menyatakan bahwa demi kesetiaan fairy rela mengembara bahkan dapat terbang lebih cepat dari pada perputaran bulan untuk mengumpulkan setiap tetesan embun. Pada Q3, penyair menyatakan dengan memberikan apa yang diinginkan Fairy Queen, maka Fairy Queen akan memberikan imbalan atau memberikan sesuatu sebagai gantinya kepada fairy yang setia kepadanya. Pada couplet (dua baris terakhir), penyair menyatakan fairy akan memberikan apapun yang dibutuhkan atau diinginkan oleh Fairy Queen agar bahagia.

\section{Simpulan}

Berdasarkan hasil penelitian dan pembahasan yang didapatkan setelah melakukan analisis pada puisi-puisi William Shakespeare, dapat disimpulkan sebagai berikut:

Pertama, terdapat 14 macam gaya bahasa di dalam puisi terpilih William Shakespeare dengan total keseluruhan mencapai 71, di antaranya: 13 metafora, 4 simile, 5 simbol, 9 personifikasi, 1 litotes, 4 hiperbola, 4 metonimia, 1 sinekdoke, 2 alusio, 10 aliterasi, 10 repetisi, 6 asonasi, 3 paralelisme, dan 2 paradoks. Kedua, gaya bahasa yang paling sering digunakan atau dominan dalam puisi William Shakespeare adalah metafora. Gaya bahasa metafora ditemukan sebanyak 13 dari 71 jumlah keseluruhan gaya bahasa yang terdapat di dalam puisi dengan persentase $17,57 \%$. Ketiga, pesan moral yang terkandung di dalam puisi terpilih William Shakespeare dengan total keseluruhan 9 pesan moral, di antaranya: 1 appreciate, 1 joy (kegembiraan karena kekuatan cinta), 4 love (cinta abadi, cinta yang dicampakkan, cinta membutakan segalanya, cinta sejati), 1 honesty, dan 1 loyalty. Di dalam penelitian ini, pesan moral yang banyak ditemukan sebagian besar tentang cinta atau kasih sayang.

Dengan adanya hasil dari penelitian ini, maka direkomendasikan saran kepada para pembaca dapat mempelajari puisi sebagai sarana untuk menambah kekayaan ilmu pengetahuan yang dimiliki. Selain itu, puisi dapat menggugah jiwa pembacanya melalui penggunaan bahasa dengan makna yang mendalam. Diharapkan untuk peneliti selanjutnya melakukan penelitian dengan pendekatan kuantitatif. Lebih lanjut, peneliti selanjutnya dapat melakukan penelitian pada aspek dan puisi lain, atau dapat meneliti dengan cakupan yang lebih luas dan komprehensif.

\section{Referensi}

Keraf, G. (2004). Diksi dan gaya bahasa. Gramedia Pustaka Utama.

Moleong, L. (2017). Metodologi penelitian kualitatif (28th ed.). Rosda.

Nurgiyantoro, B. (2010). Penilaian dalam Pengajaran Bahasa dan Sastra. BPFE.

Nurgiyantoro, B. (2015). Stilistika Kultural. Widyaparwa, 43(1), 1-14.

https://doi.org/https://doi.org/10.26499/wdprw.v43i1.89

Raflis, R., \& Zai, J. R. (2018). Figurative Languages in William Shakespeare's Poem: a Fairy Song, a Madrigal, Bridal Song, Dirge, and Sonnet 116. Jurnal Ilmiah Langue and Parole, 2(1), 53-58. https://doi.org/10.36057/jilp.v2i1.334

Shakespeare Online. (2019a). Shakespeare's Sonnets. http://www.shakespeare-online.com/sonnets/ 
Shakespeare Online. (2019b). Sonnet 113. http://www.shakespeare-online.com/sonnets/113.html Shakespeare Online. (2019c). Sonnet 116. http://www.shakespeare-online.com/sonnets/138.html Shakespeare Online. (2019d). Sonnet 138. http://www.shakespeare-online.com/sonnets/138.html Shakespeare Online. (2019e). Sonnet 18. http://www.shakespeare-online.com/sonnets/18.html Shakespeare Online. (2019f). Sonnet 29. http://www.shakespeare-online.com/sonnets/29.html Shakespeare Online. (2019g). Sonnet 55. http://www.shakespeare-online.com/sonnets/55.html Shakespeare Online. (2019h). Sonnet 94. http://www.shakespeare-online.com/sonnets/94.html Sugiyono. (2016). Metode penelitian kuantitatif, kualitatif, dan R\&D. CV. Alfabeta.

Vaughn, L. (2014). Beginning Ethics: An Introduction to Moral Philosophy. W.W. Norton. https://books.google.co.id/books?id=BwChoAEACAAJ

Waluyo, H. J. (2000). Teori dan apresiasi puisi. Erlangga.

Wellek, R., \& Warren, A. (1989). Teori kesusasteraan. Gramedia Pustaka Utama.

Wicaksono, A. (2014). Menulis kreatif sastra dan beberapa model pembelajarannya. Garudhawacana.

www.WilliamShakespeare.net. (2015). A Fairy Song by William Shakespeare. https://www.williamshakespeare.net/a-fairy-song.jsp 